\title{
Rigour in Qualitative Studies: Are we on track?
}

\author{
Ani Wilujeng Suryani ${ }^{*}$, Helianti Utami ${ }^{2}$ \\ 1,2 Department of Accounting, Universitas Negeri Malang \\ Л. Semarang 5 Malang, 65145, Indonesia \\ *Corresponding author; Email: ${ }^{1}$ ani.suryani@um.ac.id
}

\begin{abstract}
Prior research has explored qualitative studies in relation to the paradigms used. This paper enriches the literature by investigating the quality of qualitative studies in relation to the data collection method and participants' selection. In this study, we collected SNA qualitative paper proceedings from 2007 to 2017 . Guided by the minimum criteria of the data collection method described in the literature review sections, we analyze those proceedings. We found the three most common methods used in the studies: interview, observation, and documentation. The majority of the paper clearly stated their data collection method. However, only a minority of them provides a clear description of how the data were collected and how to obtain participants/data used in their studies and why invite dthem in the research. Thus, it is suggested that researchers provide a detail explanation of their methods to show the rigour of the study that they conducted.
\end{abstract}

Keywords: Qualitative studies; research quality; research method; rigour.

\section{INTRODUCTION}

Qualitative studies are now widely used and gaining considerable acceptance in social science research, including accounting discipline [14]. Over the past few years, qualitative research publications have been found growing in terms of the quantity, including in management [4] and accounting [12], [34]. The development of the use of qualitative approaches is increasing rapidly. This can be seen from the space provided for qualitative research in several leading international journals, such as Accounting, Auditing \& Accountability Journal (AAAJ), Accounting, Organizations and Society (AOS), CAR, Critical Perspectives on Accounting (CPA), European Accounting Review (EAR), JMAR, and Management Accounting Research (MAR) [12]. In addition, [12] also mentioned that qualitative research in the above journals covers several sub-fields of accounting, namely management accounting, financial accounting, auditing, and others, highlighting the relative popularity of qualitative inquiry in management accounting research.

Despite the dominance of and resistance from positivist researchers [13], [19], [51], we witness an increase of qualitative publications in Indonesia, especially in Simposium Nasional Akuntansi (hereafter SNA), one of the prestigious national accounting conference in Indonesia (see Figure 1 later in this paper). The challenge of the qualitative research lies on the question of "rigour" which is deba- table by positivist researchers. For this reason, this study aims to investigate the quality shown in qualitative studies in Indonesia.

Prior studies have investigated how qualitative research has been conducted in Indonesia (see for example, [13], [19], [51]). They discussed the reason why the authors chose qualitative research as well as the selection of research paradigms. However, the quality criteria of qualitative research are rarely studied despite the need to be transparent to enable replication [1]. A qualitative study should allow empirical or conceptual replication whereby the previous study is replicated with the same procedures but in a different population, or the same population but different procedures [2]. Hence, our paper attempts to address this gap by providing a systematic review of the qualitative papers. We contribute to the literature by providing how qualitative studies are performed and reported in developing countries. However, due to the variety of paradigm and methodology of the qualitative studies, we concentrate on the data collection method of qualitative studies.

This paper is structured as follows. First, we provide a literature review of how the data collection method should be explained in qualitative research. Next, we discuss our research design and analysis carried out in this paper. Lastly, we provide and discuss our findings and draw a conclusion. 


\section{Data Collection Methods in Qualitative Research}

In contrast to the quantitative data which are presented in numerical form, qualitative data are conveyed through words [39], [40]. This data can be in the form of quotes obtained from interviews, descriptions of activities from observation and excerpts of documents [45]. To obtain the data, researchers can choose from a broad array of methods. The most common data in qualitative research are from documentation covering minutes of a meeting, project report, including quarterly report, facility appraisal report, evaluation report, interview and focus group discussion; questionnaire survey; and observation, such as parttime review and monitoring visit [5], [9], [43], [47]. In addition, data can also be obtained from archive records and artifacts [56]. The data collection method should be carefully chosen to answer the research questions and objectives of the research [9].

In collecting research data, several fundamental principles must be considered by researchers: the usage of many sources of evidence; creation of database; and maintaining linkages between questions, evidence, and conclusions [56]. The use of multiple sources to collect data is essential to improve the reliability and validity of qualitative research findings [40], [41] by verifying facts through multiple data sources called data triangulation [22], [45].

Triangulation is the usage of more than one method or data source in a study of social phenomena [5] that can be used to check the validity of the data [56]. [15] considers triangulation as a validation strategy and differentiates it into four categories: triangulation of data, researcher, theory, and methodology. [15] further describes in detail that the triangulation of data is combining data from different sources at different times, at different places and/or different people. Triangulation of researchers involves different observers or interviewers to balance the subjective influence of the individual. Theory triangulation combines various theoretical points of view to analyses the data; while methodology triangulation uses different data collection methods. Using more than one method will result in higher confidence in the findings (Webb et. 1966 in [5]). Researchers can perform triangulation by examining observations results and comparing them with interview questions to determine the possibilities of researchers misunderstand what they have seen [5]. Triangulation is implemented by cross-checking the results of the investigation using several data collection methods [5]. The following explains the three most commonly used data collection methods: interview, observation, and documentation.

\section{Interview}

An interview is a method of data collection whereby the interviewer asks questions about the issue under investigation to the participants who answer those questions based on their knowledge or experience [30]. Interviews allow researchers to understand participants' feelings, thoughts, intentions, and perspectives, which cannot be obtained by observation [45]. An interview is recommended because it allows researchers to use probes or hints to gain clarity of response or additional information [30], 54], [56]. This can be achieved as the interview is "...flexible, responding to the direction in which interviews take the interview and perhaps adjusting the emphasis in the research as a result of significant issues that emerge in the course of interviews" ([5], p. 470).

An interview can be conducted in various ways, including face to face interviews or direct interviews and telephone interviews. Two main types of interview types in qualitative research are unstructured interviews and semi-structured interviews [3], [6]. [56] suggests using open-ended interviews during field research as it encouraged research participants to discuss issues and share their point of view. During the interview process, the researcher should avoid directing participants, instead of allowing them to express their views freely instead. Semi-structured interviews in which the researcher uses openended questions such as the question of 'what' and 'how' [21] may encourage research participants to express their opinions freely [16]. This is in line with the ontological view of qualitative research as an interview allows researchers to explore the participants' experience, understanding, and interpretation as part of social reality. In addition, the interview also conforms research epistemology because the interview is an interactive approach that 1) allows the flow of participants' interpretations; 2) enable researchers to gain a closer understanding of participants and their social worlds [27]; and 3) allows researchers to ask participants about facts and their opinions about certain things or events [3], [56].

There are some important criteria to be considered as a proper interview process:

1) An interview should be conducted with many participants with different knowledge who have the critical ability to show their views from different perspectives [18]. Using multiple informants allows obtaining multiple perspectives 
and verifying the credibility of the data. The aims of interviewing various people within an organization are to conduct subject triangulation [42] and reduce interview bias only to prominent individuals [40].

2) During the interview, the researcher records participants' responses [27]. In addition, the researcher asks for permission from the interviewee to call back to clarify some information [42]. This can be done by sending the interview transcripts later on as a confirmation strategy and obtain feedback [27], and can supplement this with a note if necessary [54].

3) In conducting interviews, the researcher should develop an interview protocol prior to the fieldwork as a guide for interviews [45]. Interview protocol is an instrument for collecting data that includes items, response categories, and instructions [30]. In the development stage, the protocol needs to be reviewed by people with expertise related to the research topic studied. The protocol shall be in accordance with the objectives of the study and provide necessary information for the interviewer to collect data/information necessary for the researcher. The protocol allows other researchers to track the data collection path used [29] replicate the research and obtain similar results [56].

4) Interview questions should be clear, using language that is easily understood by participants and in accordance with the research focus [39].

5) If a researcher wants to record the interview, he/she must have permission from the participant. The researcher then converts the recording into transcripts by listening to the recording repeatedly [40]. Transcription is then examined by researchers who listen to the recording again. To improve the credibility of the interview data, this transcription was sent to participants for final confirmation because this member validation is essential to confirm the data collected [5].

6) The researcher should be careful in determining research participants. Purposive sampling technique is recommended in qualitative research to identify key participants [44]. In such sampling techniques, it is the self-interest of the researchers who develop or set the criteria for participants [30], whereby the primary criterion is to have a detailed understanding of the phenomenon under study. The researcher should follow the saturation concept in determining the sample size (Glaser \& Strauss, 1967 in [35], whereby interview can be stopped when it reaches data saturation; when 'a new information produce little or no change to the codebook' [26, p. 65).
In summary, when examining papers with the interview as the data collection method, we explore how the researchers describe the participants (size, who, and how), the use of interview protocol, the ethical consent provided to the participants, and the confirmation strategy.

\section{Observation}

Observation is a direct observation made at the location in which the phenomenon of interest occurs naturally; observational data include informal interviews and conversations that occurred during observation [39], [45] Observation involves activities such as listening, seeing, and face to face interacting that are highly dependent on verbal and visual behaviour [46]. Spradley (1980) in [23] classifies observation into three phases: a descriptive observation that covers a broader objective, observation focused on the research problems; and selectively focused on investigating more detailed aspects. (Gold (1958) in [31] categories observation into:

- Complete participant: the observer is the member of the community being studied, but he/she obscure the researcher role

- Participant as an observer: the observer is the member of the community being studied and other members know that the researcher is studying them

- Observer as a participant: Observer participates in the group activities, but the primary role is to collect data; the members of the group aware the presence of the researcher.

- Complete observer: observer watches the activities, and the public that is being studied is not consciously observed.

Researchers conduct observations for several reasons such as to understand the context, which is essential to gain a holistic understanding [45] by paying attention directly to the participants' routine or as reference material for subsequent interviews [39]. The objective of the observation is to describe the observed location, the activities occurring within that location, the people participating in the activity and the meaning of what is observed from their observed perspectives [45]. Hence, it must be conducted systematically, linked to research questions to obtain reliable results [5], [39]. By using observation, the researcher can reveal implicit features of social life through an ongoing presence of the researcher and the ability to observe behavior which is hard to obtain by interview. Therefore, the duration that researchers devote to conduct observation will determine the depth of implicit information obtained. Regardless, observation is highly subjecttive [39] because 
researchers pay particular attention to certain things that are not noticed by others [55]; it is advantageous as a data collection technique. Observation helps to understand unclear phenomenon because it serves as a technique that can be used when an activity, event, or situation can be observed directly, when a new perspective is desired, or when the participant is unable or unwilling to discuss the topic under study. It is also a mean of triangulation of research findings; observations are used together with interviews and document analysis to reinforce findings [39], [45].

Observations can be conducted by looking at the location of the research, the interaction between subjects studied, and the practice of a particular activity. To determine what needs to be observed, the researcher needs to refer to the research objectives, problems, and questions, as well as the theoretical framework of the study [39]. Researchers can observe the relevant behaviors or environmental conditions [56]; physical circumstances, research participants, activities and interactions, conversations, subtle things, and the researcher's own behavior [39]. [6] recommended undertaking unstructured observations in qualitative research.

Prior to conducting an observation, researchers need to consider ethics when selecting key informants and, while performing the observation, decide what and when to observe [31]. During the observation, the researcher must have a field note as a record of what he/she observed [11], [17], [39] as field note is an observation data although taking note is time-consuming [49]. The notes should be made as soon as possible after the observation [3], [5], [39].

From the above description, researchers who collect data through observation need to show how they act as an observer and provide justification on this selection, whom they are observing, and how they record the observation data.

\section{Documentation}

Documents and artifacts are also sources of data in qualitative research that are available in physical and electronic form [39, [45]. Documents can be "...a wide range of written, visual, digital, and physical material relevant to the study (including visual images)" ([39] p. 162). At the same time, artifacts are "...usually three-dimensional physical 'things' or objects in the environment that represent some form of communication that are meaningful to participants and/or the setting" ([39], p. 162). Documentation may include administrative documents, studies or formal evaluations and newspaper clippings [56]; official notes, organization promotional materials, letters, newspaper accounts, poems, songs, company records, government documents, historical records, diaries, autobiographies, or blogs [39]. Another type of document is a visual document and image that can be collected and analysed in qualitative research [25], [48].

The use of documents in research is to reinforce and add to evidence from other sources and to draw conclusions and use them as guidance for an in-depth investigation [56]. Documents also strengthen the research and provide information and rich knowledge related to the phenomenon being investigated that may not be available form other data sources [38]. Researchers need to inspect documents produced by, for example, organizations such as minutes of meetings, bulletins, mission statements and work definitions because they inform researchers about what is going on within the organization and will help researchers to uncover things like culture or organizational ethos [5].

Documentation data collection is based on research questions and emerging findings, and it relies on the skills and intuition of researchers to find and interpret data from the documents [39]. For that reason, researchers need to find relevant materials and assess the authenticity and relevance of the documents [39], [56]. (Scott (1990: p.6) in [5] p. 544) proposed four criteria for assessing document quality:

1. Authenticity. Is the evidence genuine and of unquestionable origin?

2. Credibility. Is the evidence free from error and distortion?

3. Representativeness. is the evidence typical of its kind, and if not, is the extent of its untypicality know?

4. Meaning. Is the evidence clear and comprehensible?

\section{RESEARCH METHOD}

This study is a systematic literature review to exhaustively evaluate and interpret research evidence with regards to data collection of selected publications [24]. We employ qualitative content analysis, which is under qualitative descriptive design [52]. Although content analysis can be applied in a quantitative or qualitative way [50], we believe that our review fits in the qualitative content analysis because we use a subjective interpretation of the content of text data and we apply systematic use of a category system [28], [36]. Qualitative content analysis can be used in the either inductive or deductive analysis [20]. In this study, deductive approach was used whereby 
codes and categories were drawn from the quality criteria outlined in the literature review section [10], [32]. Although qualitative, the findings of the content analysis can be presented in a quantitative and qualitative way [37], so it can be in the form of figures, tables, and/or extract from the text (see for example [2], [7], [50], [53].

In doing the study, we follow four steps method proposed by [37] and [50] material collection, descriptive analysis, category selection, and material evaluation. First, our data is secondary data in which the material is collected from SNA paper proceedings. We selected articles from 20072017 and examined the year of publication, authors, subject areas, and the method applied. We chose to use SNA proceedings because SNA is one of the prestigious accounting conferences in Indonesia, whereby the papers are blind reviewed to maintain the quality of the papers. We downloaded the papers from several websites through the Google search engine with SNA proceeding as the keywords. In addition, we obtained a soft copy of the proceedings from colleagues' private collections. In total, we collected 1545 papers (excluding poster papers), about $10 \%$ of which were qualitative studies as our unit of analysis ${ }^{1}$.

Second, descriptive analysis was conducted. Since our focus is analyzing the qualitative study, we first separated qualitative studies $(n=156)$. In this step, we collected information regarding the article classification. Third, in the category selection, we examined the data collection method of those papers, whether interview ${ }^{2}$, observation, or documentation, or the combination of those three methods. This is conducted by reading all the qualitative articles, mainly in the research designs/ methodology sections to find out the data collection method that they used in the papers. We found ten papers with no clear explanation of the data collection method. Thus, these ten articles were excluded from our analysis.

Fourth, in the evaluation, we used NVivo 11 to help to sort the papers and to create nodes for each category. The nodes contained an explanation of how the authors wrote the research design in the articles. To maintain the reliability of the data analysis, the articles were re-checked manually by two research assistants. There were no disagreements on how the papers were classified, and we continued the analysis. We explored and took notes on whether the papers incorporated the minimum criteria to be regarded as an excellent qualitative study explained in the previous sections. For

1 This is our best effort to collect SNA papers. In some years, discrepancies exist between the list of accepted papers and the papers available because authors may choose to publish only the abstract.

${ }^{2}$ We classified forum group discussion into this category. instance, in the interview, the researcher should follow the saturation concept in determining sample size [26]. When analyzing the articles which mentioned the interview as a data collection method, we checked whether saturation concepts were applied in the articles. The next section shows the findings of this study.

\section{RESULTS AND DISCUSSION}

\section{Descriptive Results}

The number of authors by the paper is outlined in Table 1. Despite the relatively large number of collaborations shown in accounting research, articles with two authors dominate the writing pattern, with only $5 \%$ were written by more than three authors. This finding is not surprising in the accounting field [8], [33].

Table 1. Number of authors by article

\begin{tabular}{lcc}
\hline & Freq. & Proportion \\
\hline One author paper & 342 & $22 \%$ \\
Two authors papers & 754 & $49 \%$ \\
Three authors papers & 366 & $24 \%$ \\
Four authors, or more & 83 & $5 \%$ \\
\hline Total & $\mathbf{1 5 4 5}$ & $\mathbf{1 0 0} \%$ \\
\hline
\end{tabular}

Previous studies found that quantitative research dominates accounting papers published in Indonesia [13], [19], [51] and Figure 1 shows similar findings, although there is an increasing trend of qualitative studies. This finding indicates that Indonesian researchers start to acknowledge the qualitative approach as an alternative to the quantitative method in studying the phenomenon. Based on this data, 156 papers are qualitative studies analysed in this paper.

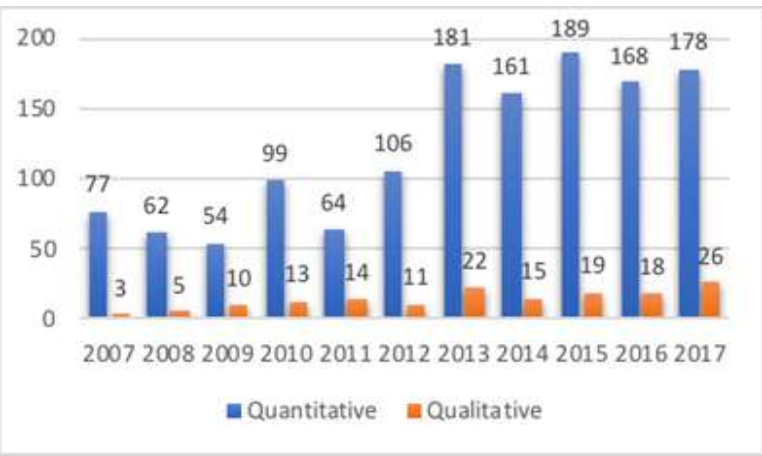

Figure 1. Articles by the research approach ${ }^{3}$

In relation to the subject category, most of the qualitative papers in SNA are $\mathrm{AKSR}^{4}$ papers (see

\footnotetext{
${ }_{3}^{3}$ We ignored mixed method studies in this figure because there are only four mixed method studies from 2007 to 2017.
} 
Figure 2). This finding indicates that there is a need to introduce qualitative research in other areas as an opportunity exists to explore cases and problems in the accounting field through qualitative research. For the research approach, phenomenology was the most commonly used with some were hermeneutics, critical, and ethnography studies.

We also found that interview was the most common method used in the study, followed by document analysis and observation (see Figure 3), although many of articles (45\%) combined at least two methods and $24 \%$ used all three methods. In 2017, there was a remarkable exception whereby document analysis method outnumbered the interview. This can be caused by the development of qualitative research in Indonesia so that authors obtain an understanding to use a broader range of data collection method in supporting their studies.
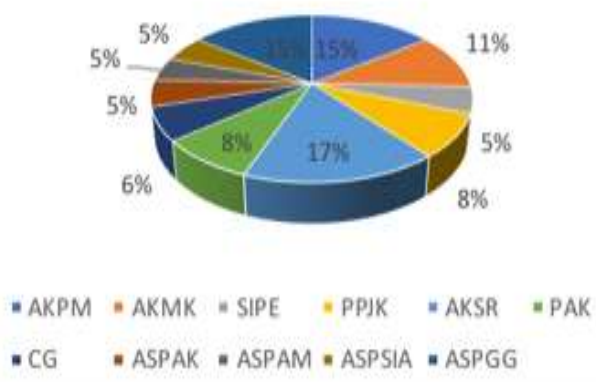

Figure 2. Qualitative papers by category

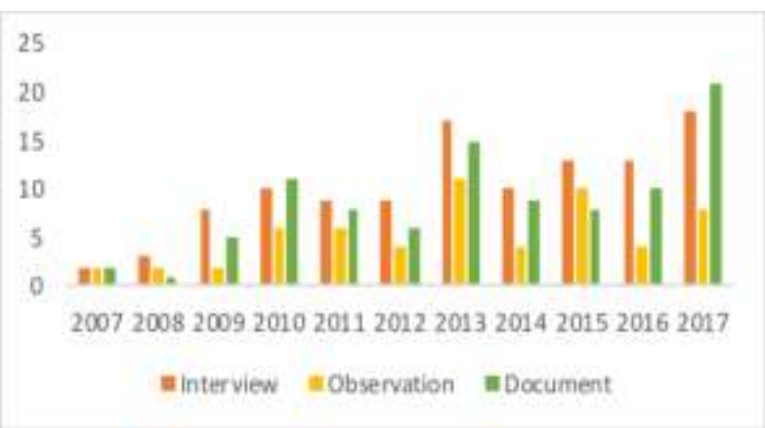

Figure 3. Papers by data collection method

\section{Findings from Studies with Interviews}

Prior to conducting an interview, it is recommended that the interviewer develop an interview protocol that consists of guidance and the questions asked [30], [45]. From our analysis of 115 papers in which data were collected through interviews, no papers explicitly show how the protocol is developed and the questions asked during the

${ }^{4}$ SNA categories paper into several group: AKSR, AKPM, SIPE, CG, ASPAK, ASPAM, ASPSIA, ASPGG, PAK, PPJK. interview (see Table 2). This finding must be carefully interpreted. We do not conclude that authors did not create a protocol during their research, rather our results indicate that authors need to report how they use the protocol in their papers to show the rigour of the study. Similarly, 32 out of 115 papers disclosed the interviews type either structured (3), semi-structured (10), or unstructured interviews (19) with limited to none justification of why these kinds of interviews fit to answer their research problems.

Table 2. Descriptive analysis of the interview

\begin{tabular}{lc}
\hline Criteria & Freq. \\
\hline Protocol & 0 \\
Interview type & 32 \\
The informants & 90 \\
Saturation & 1 \\
\hline
\end{tabular}

Although the majority of the papers showed how they selected informants, this is surprising that one-fifth of the papers did not mention anything about their informants. For example:

In this study, researchers recorded interviews with several related parties as may be necessary to be collected later described in the form of a transcript of the interview (S95) ${ }^{5}$.

Sumber data yang digunakan dalam penelitian ini adalah data primer. Teknik pengumpulan data yang digunakan dalam penelitian ini adalah wawancara dan obsrvasi (S100, the data source used in this study is primary data. The data collection methods used in this study were interview and observation)

Metode pengumpulan data yang digunakan yaitu metode observasi, wawancara dan dokumentasi dengan mencatat data dari laporan catatan dan arsip dari beberapa sumber seperti internet, jurnal, penelitian terdahulu dan sumber lain yang relevan (S136, the data collection methods used in this study involved observation, interview, and documentation by recording the data from report, notes, and archive from several sources such as internet, journal, previous studies and other relevant sources).

The above quotes suggest that for some papers, the quality of disseminating research output is below average. This can be caused by the unfamiliarity of the researchers in reporting qualitative studies, or they might think it was unnecessary to provide such details. Without

\footnotetext{
$5 \mathrm{~S}$ denotes the document number.
} 
reporting who the informants are, it is hard to decide whether the research is rigour by selecting key informants.

In contrast to participants' identity, only a minority clearly stated the sample size. Although this is not the main criterion to show the quality, stating the sample size increases the readability of the paper. Furthermore, only a few presented a detailed explanation of how participants are recruited and why. For example, some papers provided only broad participants criteria that can decrease the reliability of the research because the informant is not specified:

Sumber data dalam penelitian ini adalah mahasiswa akuntansi dan diperoleh dengan menggunakan purposive sampling (S49, the informants in this study are accounting students obtained through purposive sampling method).

Participants in this study are people who have knowledge and experience that are relevant to the research topic, have sufficient time and willing to be interviewed (S84).

Informan yang dipilih adalah orang pribadi muslim yang mengerti atau ahli masalah perpajakan. Dalam hal ini, informan adalah praktisi perpajakan serta orang yang taat beragama dan selalu menunaikan zakat (S137, the informants in this study are Muslims who understand or experts in taxation. In this study, informants are taxation practitioners, religious, and always paid their religious tax).

Although interviews were the most widely used method in this study, only one paper explicitly stated that the data collection stopped because it reached saturation (S112). This finding may indicate two things: either the researchers ignored the saturation concepts, or they did not disclose the process in their papers.

In relation to participant recruitment, we found evidence of two contrasting strategies. On one side, the author clearly explained the participants of the study and provided the notification about scheduleing the interviews (S41). On another side, three papers written by the same author mentioned that their interviews were unscheduled (S4, S14, and S42). For the purpose of replicability, the former is much easier to follow since it provided clear guidance in recruiting participants. The later, on the other hand, is hard to replicate because of unclear design about when to interview and how to obtain random participants or ensure the availability of the participants.

\section{Observation findings}

Observation is the least common method in SNA papers, and we found 69 studies collecting the data through this method. In the previous section, it is suggested that researchers who observe to show their rule as a researcher in the observation, the objects and why, and how they note their findings (see Section 2.2). Among papers with the observation method, we found that one-third did not say anything about how the observation is conducted. For example, S9 merely stated, "The evidence are found through some observations and interviews" (S9) and similar expression such as “...this study also employed observation and document analysis" (S16) was discovered in other papers. As the least chosen method in qualitative data collection, these findings may indicate that researchers put more efforts into explaining the informants for the interview rather than how they serve as an observer in their studies. These findings also suggest that researchers need to explain how they observed the phenomenon of interest to be replicable by others who want to conduct similar research.

Thirty percent of the papers indicate that they used participative observation. The explanation is also varied. Some papers only mentioned the observation type, such as:

Dalam penelitian ini teknik pengumpulan data lebih banyak pada observasi berperan serta (participant observation) dan wawancara secara mendalam (S25, in this study, data collection method relied heavily on participant observation and in-depth interview).

Data penelitian ini diperoleh melalui wawancara langsung dengan informan dan pengamatan partisipan (participant observation) (S53, the data in this study were obtained through direct interview with informants and participant observation).

Metode pengumpulan data menggunakan wawancara mendalam kepada beberapa informan, dokumentasi, dan observasi partisipatif (S107, data collection method used in this study was in-depth interview with several informants, documentation, and participant observation).

Others clarify how they do the observation and their role as researchers: 
Metode observasi partisipasi digunakan dalam penelitian ini, dengan terjun langsung dan mengamati kegiatan para pelaku usaha tenun, menganalisis pemahaman dan sejauh mana mereka mampu menerapkan akuntansi sederhana bagi usaha mereka (S83, participant observation method was used in this study to be directly involved and observed the activities of the weaving businessman, analysed the extent of their understanding and to what extent they were able to carry out simple accounting for their businesses).

Dalam rangka penelitian ini, peneliti hadir dalam berbagai kegiatan perusahaan dan menjalani kehidupan sehari-hari dengan komunitas dengan melakukan observasi partisipatif. Peneliti hadir bersama komunitas dan berpartisipasi secara aktif di level manajemen dan di beberapa kedai. Di samping itu, juga hadir dalam kegiatan-kegiatan pembukaan cabang baru perusahaan (S52, in this study, the researcher was present in various companies' activities and live among the community by conducting direct observation. The research live together with the community and actively participate in management level in several stores. In addition, researcher is also present in the opening of several business branches).

Dalam observasi ini, peneliti terlibat dengan kegiatan sehari-hari orang yang sedang diamati atau yang sedang digunakan sebagai sumber data penelitian. Sambil melakukan pengamatan peneliti ikut apa yang sedang dikerjakan oleh sumber data dan ikut merasakan suka dukanya. Dengan observasi partisipatif maka data yang diperoleh akan lebih lengkap, tajam dan sampai mengetahui pada tingkat makna dari setiap perilaku individu yang nampak (S99, in this observation, the participant was involved in daily activities of the person being observed or the informant in the study. While conducting the observation, the researcher participated in the activities conducted by the informants and experiencing what the informant has experienced. Through this participative observation, the obtained data will be more complete, accurate and able to describe up to the meaning level of each visible individual behaviour).

Although only a minority of the papers provided step-by-step observation as their data collection strategy (for example, S19, S48, S72, and
S138), the above quotes provide some evidence that some which were not rigorously showed how the observation was done. We also found some researchers published several papers during our collection periods and they continuously collect data through observation (S10, S18, S58, and S94). However, over the years, the way data collection method presented in the papers did not change significantly. This finding may suggest that research in reviewing the qualitative approach is vital to improve the quality of the publication.

In relation to the note-taking during the observation process, we found only three papers indicating this process:

Dalam hal ini peneliti melakukan pengamatan langsung dengan mengamati dan mencatat situasi yang terjadi di lapangan yang berkaitan langsung dengan tujuan penelitian (S97, direct observation was made and during that observation process the researcher take notes of things that directly tied to the objective of the study).

Kegiatan observasi meliputi melakukan pencatatan secara sistematik kejadian-kejadian, perilaku, objek-objek yang dilihat dan hal-hal lain yang diperlukan dalam mendukung penelitian yang sedang dilakukan (S118, observation activities consist of systematic note taking of events, behaviours, observed objects and other things related with the present study).

Data ini diambil melalui penggunaan alat instrumen yaitu lembar observasi, dan jurnal pengajar sebagai catatan di lapangan ( $\mathrm{S} 40$, the data in this study were taken using instruments such as observation sheet, and teacher's journal as field notes).

The above quotes showed that field notes were taken and some researchers provided observation log-book. In summary, as the least common method used as a data collection technique, observation served as additional design to support other methods, and many researchers did not bother to write the steps they taken in the research report.

\section{Documentation findings}

Documents in many forms can be used as research data [39], [45]. However, to be meaningful, they must be relevant to the research being studied. The researchers, in publishing their results, should explain the relevancy of the documents. In this study, 97 papers mentioned the use of documents as a source of data. More than 
half of the paper presented not only the documents that they were using in the study but also how they collect data in the form of documents, for example:

Prosedur pengumpulan data dalam penelitian ini dilakukan melalui studi dokumentasi data-data sekunder yang berupa dokumendokumen social. Peneliti dapat mendownload laporan tahunan dan sustainability report dengan mengakses langsung situs setiap perusahaan atau melalui website... Data-data pendukung lainnya yang meliputi PSAK, regulasi terkait CSR, prinsip-prinsip etika bisnis, berita di media, serta... (S29).

Sedangkan data tambahan berupa laporan keuangan, dokumen pribadi/resmi, sumber buku, dan surat kabar dilakukan penelaahan atas dokumen-dokumen relevan yang berhubungan dengan arsip-arsip yang dapat menunjukkan kinerja manajemen perbankan Syariah (S87).

The primary analytical approach of the study is archival and a documentary study, where the main source for the study comes from World Bank reports, speeches, minutes of meetings, meeting podcasts, articles in newspapers and magazines, and other relevant materials (101).

However, similar to findings in observation, some researchers using document analysis rarely showed what documents are used to answer the research problem. About $45 \%$ of the papers in this category did not clearly explain the documents used as exemplified in the following quotes:

Data tambahan juga didapatkan dari dokumen pendukung (S55).

Tahap yang kedua adalah pengumpulan dokumen-dokumen terkait. Dokumen-dokumen ini penting untuk mendukung hasil penelitian (S26).

We use interviews and documentation as data collection methods (S80).

To get a better overall understanding about the subject, the related documents are also being studied (S133).

The findings above indicate sloppy writing in the research method as it does not show what type of documents used in the study. This minimum information makes the research lose its rigour because no relevancy of the documents is shown.
Furthermore, five papers reported the use of documents incorrectly. Four papers mentioned that they used previous research articles, but their papers were empirical paper, not a review paper. Hence, this classification is not correct because the research articles served as a source of literature review, not as data that were analysed and become findings. Another paper stated that documents were interview transcript, but it was one of the data collection methods. Again, this is improper because the data come from the interview, not collected separately from a written text. In summary, the papers have tried to explain data collection through documents, but for a small minority, the misconception occurs in defining documents as a source of data.

\section{Other qualitative criteria}

When choosing more than one method or data source, a qualitative researcher needs to conduct a triangulation as one of the validities and credibility criteria in qualitative research [5]. In the data that we obtained, a quarter of the proceedings mentioned other qualitative standards in the method section, such as triangulation and the credibility of the research. Of these, 15 articles explicitly stated that they followed the source triangulation procedure in their method by using more than one type of data collection. Few articles described the types of triangulation, but they did not specify which type they used in their studies. For example, the definition of triangulation was provided and triangulation is aimed to "... validating findings in our research" (S80) and overcoming the limitation of the interview (S112). Similarly, S97 mentioned similar things, with a complete definition of triangulation, including the four types of triangulation. However, these papers did not clearly state which method of triangulation that they used in their research.

Some showed their specific method of triangulation, such as provided by these three papers:

... peneliti menggunakan metode triangulasi sumber, dilakukan dengan cara mendapatkan data dari sumber yang berbeda-beda melalui teknik wawancara (S91).

Untuk memastikan kualitas penelitian ini maka triangulasi metode dan prolonge engagement digunakan untuk keabsahan data (S107).

... penulis menggunakan multi sumber bukti (triangulasi) baik dari jurnal-jurnal penelitian tentang... (S106). 
Although provided the specific choice of triangulation, those papers did not clearly explain how they conducted the triangulation and how they dealt with different or contradictive findings within their sources. These findings imply that the researchers have sufficient knowledge of triangulation, but they have not articulated it clearly in their papers.

Despite many that did not provide a clear explanation, we found two with sufficient information of the triangulation strategy that can be used as a future reference:

Furthermore, based on triangulation techniques, it is needed to compare and to crosscheck the consistency of the information [45] with the aim to ensure that the data obtained is valid. This is done by comparing the observations with interviews; figure out the interview result with the documents and another literature review (S84).

Peneliti memilih triangulasi sumber untuk menguji kredibilitas data dengan cara: Pertama, membandingkan data hasil pengamatan dengan data hasil wawancara. Kedua, membandingkan apa yang dikatakan orang di depan umum dengan apa yang dikatakannya secara pribadi. Ketiga, membandingkan apa yang dikatakan orang-orang tentang situasi penelitian dengan apa yang dikatakannya sepanjang waktu (S99).

Apart from the triangulation strategy, some authors mentioned the validation procedure in their research, such as discussing the findings with experts (S70) and collecting longitudinal data (S60). One paper suggested that the validity is guaranteed with the close relationship criteria (S78) without explaining how this relationship added to the rigour of the research. These limited findings on other quality criteria provided in the paper by the authors suggest the need for further training, especially on the reporting/disseminating of the research.

\section{CONCLUSION}

This study has investigated publishing patterns in a prominent accounting conference in Indonesia based on a total of 1545 contributions published between 2007 and 2017. These contributions were analysed according to the method of data collection conducted by authors. In general, qualitative papers mostly collected data through interviews, although many papers triangulated the data collection method by using more than two data collection methods. However, the majority of the papers did not robustly explain how the data collection was conducted.

In the interviews, the authors explain in detail by mentioning aspects such as the informants and research site. While the interview received attention from the researchers, observation and documenttation served as a complement to the interviews. This was shown by the exposure of this technique in the method section of the paper whereby the authors mostly clarify the type of observation and the presence of the document as the data. Hence, this paper is expected to provide a brief guide of the minimal criteria to be reported in the research output, such as proceeding or journal articles.

Several worthwhile avenues for further research arise from this study. First, as noted in earlier sections, the sample selected is limited to national accounting proceedings papers during an eleven-year period. An opportunity exists to perform a similar analysis on a larger sample that would also capture the articles published in reputable national journals. This extension would enhance claims as to the breadth of qualitative data collection patterns in accounting journals. While the analysis processes in this study are limited to the research method section of the paper, future studies could include the findings in the analysis to permit more comprehensive studies in the triangulation and other validity procedures. While this article has articulated certain qualitative data collection patterns in contributions to the proceedings, future research is encouraged to explore the propensity of researchers to collaborate with authors located in other institutions. A researcher might also examine further into the reason for a qualitative study in particular subject categories and why other categories of accounting research remain entirely or virtually ignored.

\section{REFERENCES}

[1] Aguinis, H., Ramani, R. S., and Alabduljader, N. (2018). What you see is what you get? Enhancing methodological transparency in management research. Academy of Management Annals, 12(1), 83-110.

[2] Aguinis, H., and Solarino, A. M. (2019). Transparency and replicability in qualitative research: The case of interviews with elite informants. Strategic Management Journal, 40(8), 1291-1315.

[3] Bruce, B., and Berg, M., Qualitative research methods for the social sciences, Fourth Edi., Long Beach: California State University, 2001. 
[4] Bluhm, D. J., Harman, W., Lee, T. W., and Mitchell, T. R. (2011). Qualitative research in management: A decade of progress. Journal of Management Studies, 48(8), 1866-1891.

[5] Bryman, A., Social research methods, Fourth Edi, Oxford University Press., 2012.

[6] Bryman, A., and Bell, E. (2007). Business research methods. Oxford University Press.

[7] Burla, L., Knierim, B., Barth, J., Liewald, K., Duetz, M., and Abel, T. (2008). Intercoder reliability assessment. Nursing Research, 57(2), 113-117.

[8] Carnegie, G. D., and Potter, B. N. (2000). Publishing patterns in specialist accounting history journals in the English language, 1996-1999. Accounting Historians Journal, 27(2), 177-198.

[9] Carter, S. M., and Little, M. (2007). Justifying knowledge, justifying method, taking action: epistemologies, methodologies, and methods in qualitative research. Qualitative Health Research, 17, 1316-1328.

[10] Cavanagh, S. (1997). Content analysis: Concepts, methods and applications. Nurse Researcher, 4(3), 5-16.

[11] Creswell, J. W., Qualitative inquiry and research design: choosing among five approaches, Third Edi, Sage Publication., London, 2013.

[12] Dai, N. T., Free, C., and Gendron, Y. (2019). Interview-based research in accounting 20002014: Informal norms, translation and vibrancy. Management Accounting Research, 42, 2638.

[13] Darmayasa, I Nyoman, and Aneswari, Y. R. (2015). Paradigma Interpretif pada Penelitian Akuntansi Indonesia. Jurnal Akuntansi Multiparadigma, 6(3), 350-361.

[14] Decrop, A. (1999). Triangulation in qualitative tourism research. Tourism Management, 20(1), 157-161.

[15] Denzin, N. K., The Research Act: A theoretical Introduction to Sociological Methods, McGraw Hills., New York, 1978.

[16] Doolin, B. (1996). Alternative views of case research in information systems. Australian Journal of Information Systems, 3, 21-29.

[17] Eisenhardt, K. M. (1989). Building theories from case study research. Academy of Management Review, 14(4), 532-550.

[18] Eisenhardt, K. M., and Graebner, M. (2007). Theory building from cases: opportunities and challenges. Academy of Management Journal, 50(1), 25-32.

[19] Ekasari, K. (2014). Menerawang Riset Akuntansi Di Pendidikan Vokasi Di Masa Depan. Prosiding Simposium Nasional Akuntansi Vokasi, 3, 404-414.
[20] Elo, S., and Kyngäs, H. (2008). The qualitative content analysis process. Journal of Advanced Nursing, 62(1), 107-115.

[21] Eriksson, P., and Kovalainen., Qualitative methods in business research, Sage Publication., London, 2008.

[22] Flick, U., Managing quality in qualitative research. Sage Publications., London, 2008.

[23] Flick, U., Kardorff, E. V., and Steinke, I., $A$ companion to Qualitative Research. Sage Publications., London, 2004.

[24] Glasziou, P., Irwig, L., Bain, C., and Colditz, G., Systematic Reviews in Health Care, Cambridge University Press., Cambridge, 2001.

[25] Grady, J. (2008). Visual research at the crossroads. Qualitative Social Research, 9(3).

[26] Guest, G., Bunce, A., and Johnson, L. (2006). How many interviews are enough? An experiment with data saturation and variability. Field Methods, 18(1), 59-82.

[27] Hermanowicz, J. C. (2002). The great interview: 25 strategies for studying people in bed. Qualitative Sociology, 25(4), 479-499.

[28] Hsieh, H. F., and Shannon, S. E. (2005). Three approaches to qualitative content analysis. Qualitative Health Research, 15(9), 12771288.

[29] Irani, Z., Ezingeard, J., Grieve, R., and Race, P. (1999). A case study strategy as part of an information systems research methodology: a critique. The International Journal of Computer Applications in Technology, 12(2), 190198.

[30] Johnson, B., and Christensen, L., Educational research: Quantitative, qualitative, and mixed approaches, Second Edi, Pearson., Sydney, 2004.

[31] Kawulich, B. (2005). Participant observation as a data collection method. Forum: Qualitative Social Research Sozialforchung, 6(2), 1-32.

[32] Kondracki, N. L., Wellman, N. S., and Amundson, D. R. (2002). Content analysis: Review of methods and their applications in nutrition education. Journal of Nutrition Education and Behavior, 34(4), 224-230.

[33] Lukka, K., and Kasanen, E. (1996). Is accounting a global or a local discipline? Evidence from major research journals. Accounting, Organizations and Society, 21(7-8), 755-773.

[34] Malsch, B., and Salterio, S. E. (2016). "Doing good field research": Assessing the quality of audit field research. Auditing: A Journal of Practice and Theory, 35(1), 1-22.

[35] Mason, M. (2010). Sample size and saturation in $\mathrm{PhD}$ studies using qualitative interviews. Forum: Qualitative Social Research Sozialforschung, 11(3), 8 . 
[36] Mayring, P. (2000). Qualitative content analysis. Forum: Qualitative Social Research, 1(2). Retrieved from http://217.160.35.246/fqs-texte/ 2-00/2-00mayring-e.pdf

[37] Mayring, P. (2008). Qualitative Inhaltanalyse - Grundlagen und Techniken (Qualitative Content Analysis). Weinheim: Beltz Verlag.

[38] McDonald, V., Before-and-after case study design. In A.J. Mills, G. Eurepos, and E. Wiebe (Eds), Encyclopedia of Case Study Research, Sage Publication, Inc., Thousand Oaks, 2010.

[39] Merriam, and Tisdell., Qualitative research: a guide to design and implementation, Fourth Edi, Jossey-Bass: a Wiley Brand., San Fransisco, 2016.

[40] Miles, M. B., and Huberman, A. M., Qualitative data analysis: an expanded sourcebook, Second Edi, Sage Publications., London, 1994.

[41] Myers, M. D., Qualitative research in business and management, Sage Publications., London, 2009.

[42] Myers, M. D., and Newman, M. (2007). The qualitative interview in Is research: examining the craft. Information and Organization, $17,2-26$.

[43] Naela, P., Thapa, S., and Boyce, C., Preparing a case study: a guide for designing and conducting a case study for evaluation input, Pathfinder Internasional., Ghana, 2006.

[44] Neuman, W., Social research methods: qualitative and quantitative approaches, Pearson Education., London, 2003.

[45] Patton, M. Q., Qualitative research and evaluation methods, Fourth Edi, Sage., Thousand Oaks, 2015.

[46] Punch, K. F., Introduction to social research: quantitative and qualitative approaches, Sage Publications., London, 1999.
[47] Ritchie, J., and Lewis, J., Qualitative research practice: a guide for social science students and researchers, Sage Publications., London, 2003.

[48] Pink, S., Doing visual ethnography, Sage., Thousand Oaks, 2013.

[49] Schensul, J. J., and LeCompte, M. D., Essential ethnographic methods: a mixed methods approach. Ethnographer's toolkit, Second Edi. AltaMira Press., Lanham, 2013.

[50] Seuring, S., and Gold, S. (2012). Conducting content-analysis based literature reviews in supply chain management. Supply Chain Management, 17(5), 544-555.

[51] Suyunus, Mohamad. (2018). Ketika Paradigma Positif Mendampingi Paradigma NonPositif Dalam Riset Akuntansi. EKUITAS (Jurnal Ekonomi Dan Keuangan), 16(4), 409432.

[52] Vaismoradi, M., Jones, J., Turunen, H., and Snelgrove, S. (2016). Theme development in qualitative content analysis and thematic analysis. Journal of Nursing Education and Practice, 6(5).

[53] Vourvachis, P., and Woodward, T. (2015). Content analysis in social and environmental reporting research: trends and challenges. Journal of Applied Accounting Research, 16(2), 166-195.

[54] Walsham, G. (1995). Interpretive case studies in IS research: nature and method. European Journal of Information Systems, 4, 74-81.

[55] Wolcott, H. F., Posturing in qualitative inquiry. In M.D. LeCompte, W.L. Millroy, and $J$. Preissle (Eds), the handbook of qualitative research in education, FL: Academic Press., Orlando, 1992.

[56] Yin, R. K., Case study research: design and methods, Third Edit. Sage Publication., California, 200. 